\title{
Response of Coral Reef Dinoflagellates to Nanoplastics under Experimental Conditions Suggests Downregulation of Cellular Metabolism
}

\author{
Christina Ripken ${ }^{1,2, * \mathbb{C}}$, Konstantin Khalturin ${ }^{2}$ and Eiichi Shoguchi ${ }^{2}$ \\ 1 Light-Matter Interactions for Quantum Technologies Unit, Okinawa Institute of Science and Technology \\ Graduate University, Onna, Okinawa 904-0495, Japan \\ 2 Marine Genomics Unit, Okinawa Institute of Science and Technology Graduate University, Onna, \\ Okinawa 904-0495, Japan; konstantin.khalturin@oist.jp (K.K.); eiichi@oist.jp (E.S.) \\ * Correspondence: christina.ripken@oist.jp
}

Received: 25 September 2020; Accepted: 5 November 2020; Published: 9 November 2020

\begin{abstract}
Plastic products contribute heavily to anthropogenic pollution of the oceans. Small plastic particles in the microscale and nanoscale ranges have been found in all marine ecosystems, but little is known about their effects upon marine organisms. In this study, we examine changes in cell growth, aggregation, and gene expression of two symbiotic dinoflagellates of the family Symbiodiniaceae, Symbiodinium tridacnidorum (clade A3), and Cladocopium sp. (clade C) under exposure to $42-\mathrm{nm}$ polystyrene beads. In laboratory experiments, the cell number and aggregation were reduced after 10 days of nanoplastic exposure at $0.01,0.1$, and $10 \mathrm{mg} / \mathrm{L}$ concentrations, but no clear correlation with plastic concentration was observed. Genes involved in dynein motor function were upregulated when compared to control conditions, while genes related to photosynthesis, mitosis, and intracellular degradation were downregulated. Overall, nanoplastic exposure led to more genes being downregulated than upregulated and the number of genes with altered expression was larger in Cladocopium sp. than in S. tridacnidorum, suggesting different sensitivity to nano-plastics between species. Our data show that nano-plastic inhibits growth and alters aggregation properties of microalgae, which may negatively affect the uptake of these indispensable symbionts by coral reef organisms.
\end{abstract}

Keywords: nanoplastics; dinoflagellate; coral reef; Symbiodinium; Cladocopium; gene expression

\section{Introduction}

Coral reefs provide a habitat for marine invertebrate and vertebrate species alike, sustaining the highest biodiversity among marine ecosystems [1]. Formed primarily by scleractinian corals and coralline algae, coral reefs are complex and vulnerable ecosystems. Structural complexity of coral reefs, and, by extension, the capability to sustain biodiversity often declines due to natural and human-related stressors [2,3].

One important stressor for coral reef ecosystems is plastic pollution. Small plastic particles $\left(>1 \mathrm{~mm}\right.$ ) have been reported from coral islands at more than $1000 \mathrm{items} / \mathrm{m}^{2}$ [4]. Further fragmentation of these particles leads to nano-plastics $(<1 \mu \mathrm{m})$ [5]. Microplastic particles induce stress responses in scleractinian corals, and suppress their immune systems and capacity to cope with environmental toxins [6]. When ingested by corals [7-9], microplastics disrupt the anthozoan-algal symbiotic relationship [10]. They are also linked to potential adverse effects on calcification [11] with exposure resulting in attachment of microplastic particles to tentacles or mesenterial filaments, ingestion of microplastic particles, and increased mucus production [12]. Su et al. [13] exposed the coral 
symbiont, Cladocopium goreaui, to 1- $\mu$ m polystyrene spheres, leading to diminished detoxification activity, nutrient uptake, and photosynthesis as well as increased oxidative stress, apoptosis levels, and ion transport. Plastic particles seem to negatively impact symbiotic relationships between corals and their microalgae, thereby degrading the entire coral reef ecosystem. However, this has not been systematically investigated.

Nano-plastics can originate by fragmentation of larger plastic objects through photochemical and mechanical degradation. There are also primary sources of nano-plastics. Medical and cosmetic products, nanofibers from clothes and carpets, 3D printing, and Styrofoam byproducts find their way into coral reef ecosystems via river drainages, sewage outfalls, and runoff after heavy rainfall, as well as via atmospheric input and ocean currents. Nano-plastics have recently been reported in ocean surface water samples [14]. Since the nanoplastic research is still in its infancy, many unanswered questions remain, starting with the environmental concentrations in various ecosystems $[15,16]$. Since detecting nano-plastics' concentrations directly is still not possible [17], a better understanding of the potential impacts is necessary to encompass a range of different concentrations. The miniature size of these particles leads to higher surface area to volume ratios and enhanced reactivity of smaller particles coupled with the ability to pass across biological barries and enter cells [18] when compared to micro-plastics.

In this study, we focused on the microalgal symbionts of mollusks that inhabit fringing coral reefs of Okinawa. Knowledge of the effects of nano-plastics on the symbionts of Tridacninae (giant clams) and Fraginae (heart cockles) will benefit conservation and restocking efforts, since both are obligatory photo-symbionts and important contributors to coral reef ecosystems. Approximately 30 Symbiodiniaceae phylotypes are economically important for fisheries [19]. This study specifically investigated effects of nano-plastics (42-nm polystyrene spheres) on the growth rates, aggregations, and gene expression changes in Symbiodinium tridacnidorum (symbionts of the Tridacninae) and Cladocopium sp. (symbionts of the Fraginae).

\section{Materials and Methods}

\subsection{Exposure to Nano-Plastics Using Roller Tanks}

The majority of host animals obtain their indispensable symbiotic dinoflagellates from coral reef sand and the water column [20,21]. Roller tanks and tables were used to simulate the natural environment of the dinoflagellate vegetative cells in their free-living state [22,23]. Roller tanks have commonly been used to promote aggregation since Shanks and Edmondson [23,24]. Fifteen roller tanks of $13.4 \mathrm{~cm}$ in diameter and $7.5 \mathrm{~cm}$ in height with a capacity of $1057 \mathrm{~mL}$ were employed. In tanks, aggregation can occur [23], ensuring that microalgae are exposed to the polystyrene nano-plastics (nanoPS) in a way that mimics their natural habitat. Once rotation commenced, continuous aggregate formation and suspension were ensured [24] as well as continuous exposure to nanoPS. Roller tanks are closed for the entire duration of the experiment, so that exposure levels of the nanoPS remain constant throughout. Tanks were closed without bubbles so as not to disturb the aggregation process with turbulence. To compare differences between species, two dinoflagellates, Symbiodinium tridacnidorum (clade A3 strain, ID: NIES-4076) and Cladocopium sp. (clade C strain, ID: NIES-4077) were cultured in artificial seawater containing $0.2 \times$ Guillard's (F/2) marine-water enrichment solution (Sigma-Aldrich) in roller tanks $[25,26]$. S. tridacnidorum and Cladocopium sp. were isolated from Tridacna crocea and Fragum sp. in Okinawa, Japan [25]. Using glass flasks, precultures for the stress experiment were established, as previously described [26].

Microplastics (>1 mm) from a coral reef and the ingestion (53 to $500 \mu \mathrm{m}$ ) by coral reef clams have been reported and microplastic removal by giant clams has been proposed [4,27]. To simulate nano-plastic accumulation in coral reefs and in the host organisms, three different concentrations $(0.01 \mathrm{mg} / \mathrm{L}, 0.1 \mathrm{mg} / \mathrm{L}$, and $10 \mathrm{mg} / \mathrm{L})$ of nano-plastic (42-nm pristine polystyrene beads, nanoPS $_{42}$, from Bangs Laboratories Inc., catalog number FSDG001, polystyrene density $1.05 \mathrm{~g} / \mathrm{cm}^{3}$, nanoPS) 
were added to the treatment tanks (Table S1). Preliminary tests were run to confirm no leaching of the fluorescent dye (data not shown). Concentrations were chosen to span a range of possible environmental concentrations, starting at $0.01 \mathrm{mg} / \mathrm{L}$ with a surface area of $1.36 \times 10^{6} \mu \mathrm{m}^{2} / \mathrm{L}$ and $2.46 \times 10^{8}$ particles per $\mathrm{L}$. The next highest concentration is just one magnitude higher $(0.1 \mathrm{mg} / \mathrm{L}$, surface area $1.36 \times 10^{7} \mu \mathrm{m}^{2} / \mathrm{L}$ and $2.46 \times 10^{9}$ particles per $\mathrm{L}$ ). This middle range concentration corresponds to actually observed lower concentrations of microplastic particles [28]. Just as microplastic concentrations are highly variable, nanoplastic concentrations are assumed to change depending on the proximity to human activity. To account for these variables, but not at the highest measured microplastic concertation, we placed our highest concentration at $10 \mathrm{mg} / \mathrm{L}$ with a surface area of $1.36 \times 10^{9} \mu \mathrm{m}^{2} / \mathrm{L}$ and $2.46 \times 10^{11}$ particles per L (Table S1). Treatment tanks as well as control tanks (no nanoPS) were established in triplicate. Three tanks without algae were prepared as negative controls $($ at $10 \mathrm{mg} / \mathrm{L}$, $0.01 \mathrm{mg} / \mathrm{L}$, and $0 \mathrm{mg} / \mathrm{L}$ nano-plastic). In each culture tank, the final cell density of the two strains was adjusted to $\sim 7 \times 10^{5}$ cells $/ \mathrm{mL}$. Tanks were harvested after 9-11 days for logistical reasons, making replicates a day apart (Table S2).

\subsection{Measurements of Cell Density and Aggregation}

Cells for growth rates were counted using hemocytometers (C-Chip DHC-N01) under a Zeiss Axio Imager Z1 microscope (Jena, Germany). At least two subsamples and 200 cells were counted per sample.

Aggregates were imaged and counted in each tank and for five size classes, as follows: $0.2-0.5 \mathrm{~mm}$, $0.5-1 \mathrm{~mm}, 1-2.5 \mathrm{~mm}, 2.5-3.5 \mathrm{~mm}$, and $>3.5 \mathrm{~mm}$ in the longest dimension. Tanks of the same concentration were sampled at the same time of day. Controls were sampled first and then in order of increasing nanoPS 42 concentration to avoid nano-plastic carry over from higher concentrations to lower. In order to examine how nanoPS 42 affects aggregate formation, aggregates were collected for different measurements after the approximate total number of aggregates in each tank had been determined. Aggregation of algae and plastic was confirmed with 3D imaging using a Zeiss Lightsheet Z.1 and Imaris software. NanoPS 42 was observed with a band-pass filter (excitation: $405 \mathrm{~nm}$, emission: 505-545 nm) and chloroplasts were visualized using a long-pass red filter (excitation: $488 \mathrm{~nm}$, emission: $660 \mathrm{~nm})$.

One fourth of all aggregates were collected for RNA analysis (2 min spin down at 12,000 rpm and discarding the supernatant, freezing in liquid nitrogen, and storage at $-80^{\circ} \mathrm{C}$ ). For all other measured factors, harvest included separate sampling of the aggregate fraction (aggregates $>0.5 \mathrm{~mm}, \mathrm{Agg}$ ) and the surrounding sea water fraction (aggregates $<0.5 \mathrm{~mm}$ and un-aggregated cells) [29]. Aggregates for sinking velocity (three aggregates per size class for $11.5 \mathrm{~cm}$ in a 100-mL glass graduated glassware cylinder) was collected in artificial seawater at the same temperature as experiments were conducted.

\subsection{RNA Extraction, Library Construction, and Sequencing}

Frozen cells were broken mechanically using a polytron (KINEMATICA Inc., Luzern, Switzerland) in tubes chilled with liquid nitrogen. RNAs were extracted using Trizol reagent (Invitrogen) according to the manufacturer's protocol. The quantity and quality of total RNA were checked using a Qubit fluorometer (ThermoFisher, Waltham, MA) and a TapeStation (Agilent, Santa Clara, CA), respectively. Libraries for RNA-seq were constructed using the NEBNext Ultra II Directional RNA Library Prep Kit for Illumina (\#E7760, NEB). Sequencing was performed on a NovaSeq6000 SP platform. Nine mRNA-seq libraries from nanoPS-exposed photosymbiotic algae were sequenced ( 3 concentrations $\times 3$ exposure times) plus three controls (Table S2).

\subsection{RNA-Seq Data Mapping and Clustering Analysis}

Raw sequencing data obtained from the NovaSeq6000 were quality trimmed with Trimmomatic (v. 0.32) in order to remove adapter sequences and low-quality reads. Paired reads that survived the trimming step (on average 92\%) were mapped against reference transcripts of Symbiodinium 
and Cladocopium sp. For each gene in the genomes of Symbiodinium and Cladocopium sp. a *.t1 transcript form was used as a reference sequence. Mapping was performed using RSEM (RNA-Seq by Expectation-Maximization) [30] with the bowtie (v. 1.1.2) as an alignment tool. Expression values across all samples were normalized by the TMM (Trimmed Mean of $M$-values) method [31]. Genes with differential expression (two-fold difference and $p<0.001$ ) were identified with edgeR Bioconductor, based on the matrix of TMM normalized TPM Transcripts Per Kilobase) values. Experimental samples were clustered according to their gene expression characteristics using edgeR. Annotations were performed using BLAST2GO and Pfam databases [25] and are available at the genome browser site (https://marinegenomics.oist.jp).

\section{Results and Discussion}

\subsection{Suppression of Algal Growth by Nano-Plastic Exposure}

Exposure to nanoPS $\mathrm{S}_{42}$ decreased the mean growth rate of photosymbiotic algae (Figures 1 and S1). The greatest reduction in growth rate was seen at the lowest nanoPS ${ }_{42}$ treatment $(0.01 \mathrm{mg} / \mathrm{L})$ with cell densities reduced from starting values by $-0.062 \pm 0.02$ (Holm-Sidak, $p=0.002$ ), which was followed by the highest nanoPS 42 treatment $(10 \mathrm{mg} / \mathrm{L})$ with $-0.013 \pm 0.05$ (Holm-Sidak, $p=0.026)$. In the $0.1 \mathrm{mg} / \mathrm{L}$ treatment, cell densities increased slightly by $0.028 \pm 0.04$. Thus, nanoPS ${ }_{42}$ either inhibited algal growth in a non-linear manner or had a limited effect [32]. Reductions in growth rates have also been reported in the micro-plastic study of Reference [13] in Cladocopium goreaui and in other microalgae exposed to micro-plastics (Chlamydomonas reinhardtii [33] and Skeletonema costatum [34]).

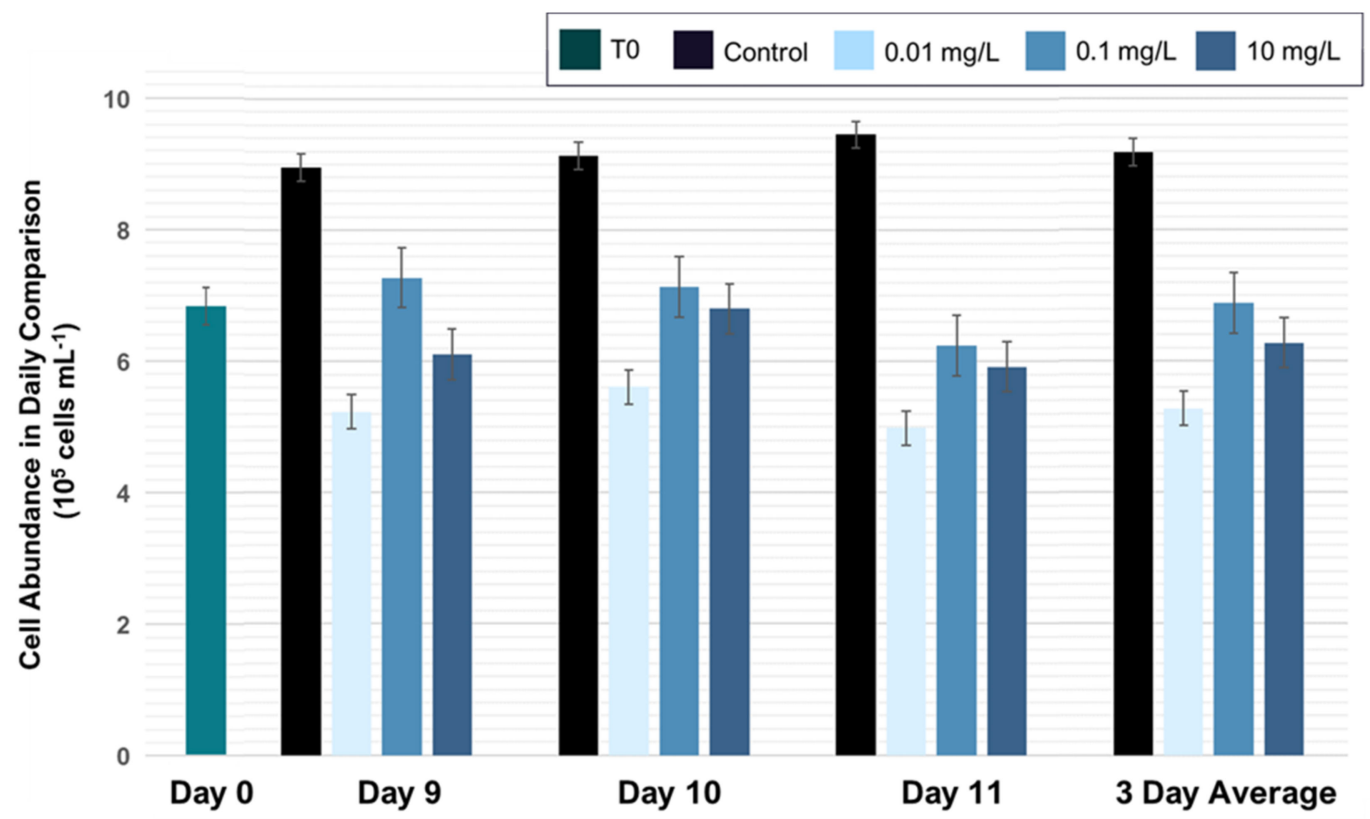

Figure 1. Treatment and control tanks were sampled after 9, 10, and 11 days. Experiments started with $\sim 680,000$ cells $/ \mathrm{mL}$ in all tanks. There are differences between the growth rate in the different treatments, but the ratio stays the same over all three sampling days. The cell density in the control was $9.83 \pm 0.39 \times 10^{5}$ cells per $\mathrm{mL}$, while treatment tanks were significantly lower: $0.01 \mathrm{mg} / \mathrm{mL}$ : $5.69 \pm 0.12 \times 10^{5}$ cells per $\mathrm{mL}, 0.1 \mathrm{mg} / \mathrm{mL}: 7.51 \pm 0.34 \times 10^{5}$ cells per $\mathrm{mL}$, and $10 \mathrm{mg} / \mathrm{mL}: 6.96 \pm 0.40 \times 10^{5}$ cells per $\mathrm{mL}$. Bars display a confidence interval.

In addition, Su et al. [13] reported a reduction in cell size in Cladocopium goreaui. Further investigations are needed to see if this is the case under nano-plastic exposure. The biggest growth rate reduction observed was at $0.01 \mathrm{mg} / \mathrm{L}$ nanoPS ${ }_{42}$, which is far below the $5 \mathrm{mg} / \mathrm{L}$ used by $\mathrm{Su}$ et al. [13]. The nutrient deficiency is also a reason discussed in Reference [23], which could 
explain the larger effects on growth rates at lower concentrations. The reason for nutrient limitation induced by plastic is proposed to be interactions of the nutrients with the surface of the plastics [35]. $\mathrm{NanoPS}_{42}$ self-aggregation could account for the higher nanoPS 42 treatments having less of an effect on the growth rates.

\subsection{Nano-Plastic Exposure Influences the Number and Sinking Velocity of Cell Aggregates}

To understand the impact of nanoPS 42 on aggregation in these two Symbiodiniaceae cultures, the total number of algal aggregates per tank and in five aggregate class sizes was recorded (Figures 2 and S2). All tanks showed aggregation, which was expected, as self-aggregation of Symbiodiniaceae has been observed previously [13].

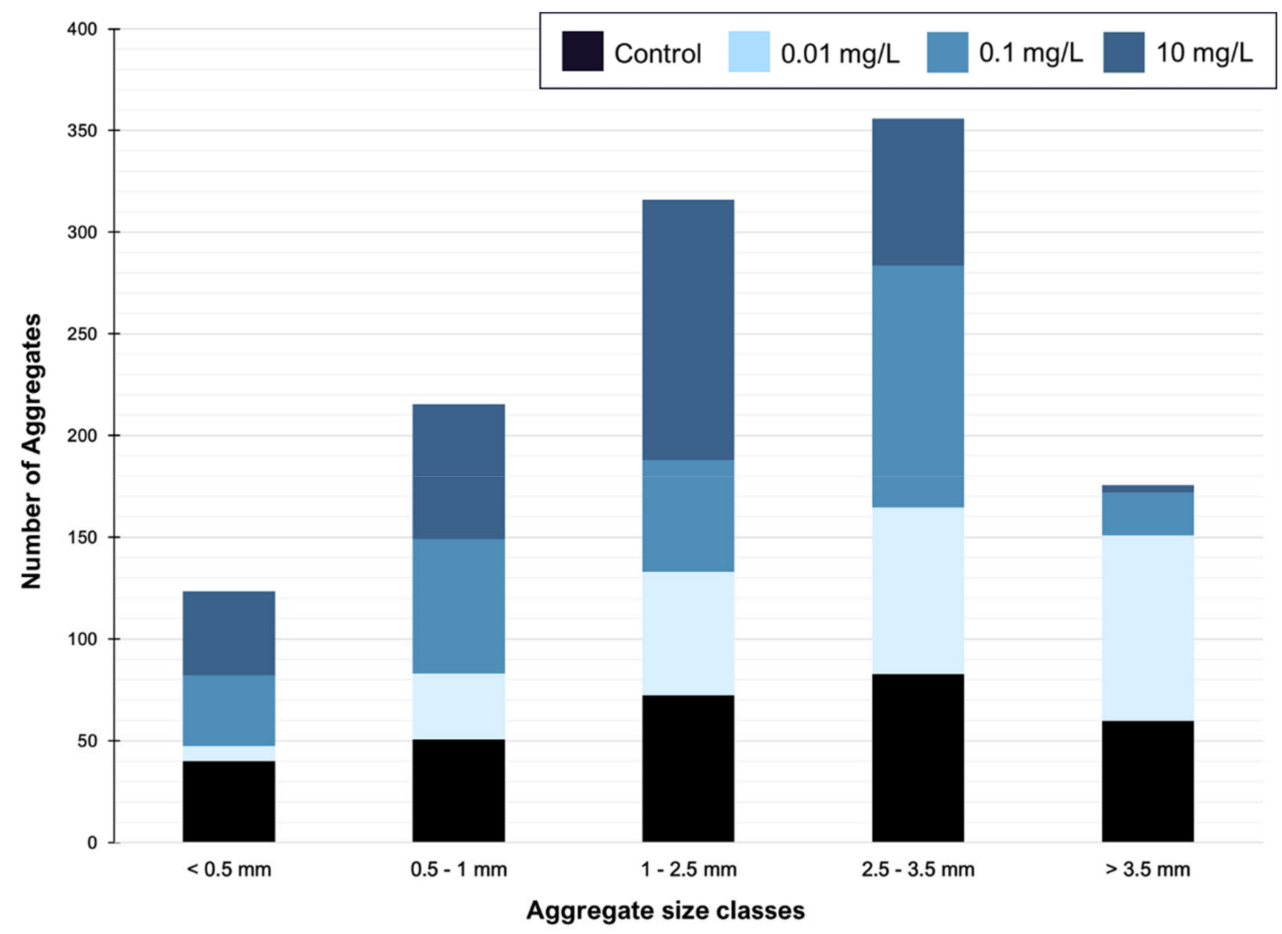

Figure 2. NanoPS exposure leads to a change in aggregation. Aggregates sorted by class size show a significant change in the distribution pattern under nanoPS ${ }_{42}$ exposure (Holm-Sidak, $p=0.05$ ). No differences are observed when exposure length is compared.

The majority of aggregates exhibited an ovoid form. A significant difference can be observed when aggregate numbers are compared over all class sizes and all treatments, showing that the nanoPS has an influence on the aggregation process. The lowest nanoPS 42 treatments $(0.01 \mathrm{mg} / \mathrm{L}) \mathrm{shows}$ significant reduction in the total aggregates count by $10 \%$ (Holm-Sidak, $p=0.003$ ), but aggregation was enhanced overall in that treatment to have a higher percentage of huge aggregates than in the control treatment (Holm-Sidak, $p=0.001)$. While there is also a reduction of $3 \%$ in the intermediate nanoPS $_{42}$ treatment $(0.1 \mathrm{mg} / \mathrm{L})$, this is not significant (Holm-Sidak, $\left.p=0.319\right)$. In the highest plastic treatment at $10 \mathrm{mg} / \mathrm{L}$, this is reversed, leading to more aggregates overall, and more of those being of smaller sizes. The different aggregate class sizes show significantly different distributions in all three treatments and the control (ANOVA, $p<0.001$ ) (Figure S2). In the control, the self-aggregation led to a specific distribution pattern of aggregate sizes, which was not repeated in the treatments. Self-aggregation was also observed in the microplastic experiments of Su et al. [13]. The fact that the presence of nanoPS changes the aggregation between the cells and leads to more aggregates in the bigger size classes is possible due to higher production of extracellular polymeric substances (EPS) with sticky properties, trapping more cells in one aggregate and keeping aggregates closer together. 
Nutrient depletion, which has been linked to the presence of micro-plastics in algae cultures [35], is associated with increased stickiness of the EPS [36,37]. Differences in the EPS production due to the presence of nanoPS is a likely factor contributing to the differences in aggregation seen in the study. EPS production was not measured, so further studies are needed to confirm this hypothesis linking the aggregation process and EPS production in Symbiodiniaceae under nanoPS influence. Lagarde et al. [33] notices different aggregate formation under different plastic treatment and sizes, which matches with our results. In addition, in Symbiodinium tridacnidorum, genes encoding a protein with a TIG (Transcription factor immunoglobulin) domain were upregulated. Since this protein is found in surface cell receptors, it may influence changes in hetero aggregation.

Significant differences are evident when aggregate numbers are compared over size classes and treatments, showing that nanoPS influences aggregation. Aggregate size classes show significantly different distributions in all three treatments vs. controls (ANOVA, $p<0.001$ ) (see Figure 2). These differences in aggregation could be due to changes of the cell surface receptors, as nanoPS increases genes related to those two-fold (see Section 3.3. NanoPS effects on gene expression).

Due to nanoPS exposure, aggregation and sinking velocities are impacted, which, in turn, leads to change in sedimentation. Since the majority of the host animals obtain their symbiotic dinoflagellates from the sand and water column [20], these changes in dinoflagellate sedimentation might lead to problems in acquisition of symbionts for the host animals. The lowest plastic treatment used, which is environmentally possible, already induces changes to the sedimentation. This lowest treatment led to bigger aggregates, which, at the same time, sank faster, possibly removing the symbionts from the water column faster than required from the host animals and reducing chances of encountering symbionts.

Changes in aggregation and resulting sedimentation were observed under nanoPS exposure (Figure 3). The biggest changes in sinking velocity correspond to increases in aggregation and are observed in the lowest plastic treatment at $0.01 \mathrm{mg} / \mathrm{L}$. On the other hand, the $10 \mathrm{mg} / \mathrm{L}$ treatment did not have any significant effect on the sinking rates but did affect sedimentation indirectly through changes in the aggregate size distribution (Figure 3). These changes, including both sinking velocities and aggregate size distribution, are most likely due to hetero-aggregation between algae and nanoPS. Under different treatments, the size distribution of aggregates was significantly different (Figure 2). In combination, it is likely that the same effect that led to that difference in aggregation is also responsible for the difference in sinking velocities. Changes in EPS production and stickiness will lead to different cell packaging within the aggregates, possibly creating tighter packed aggregates in the lowest and intermediate treatment. This effect might be counteracted under the highest nanoPS exposure by the sheer volume of EPS, which is lighter than seawater. The nano-plastic itself trapped in these could also add to the sinking velocity returning back to control levels in the high plastic treatments. Since these symbionts are paired with the mobile larvae of the host animals, a higher sinking velocity would remove the potential symbiont from the pelagic area and reduce the chance of a match. 


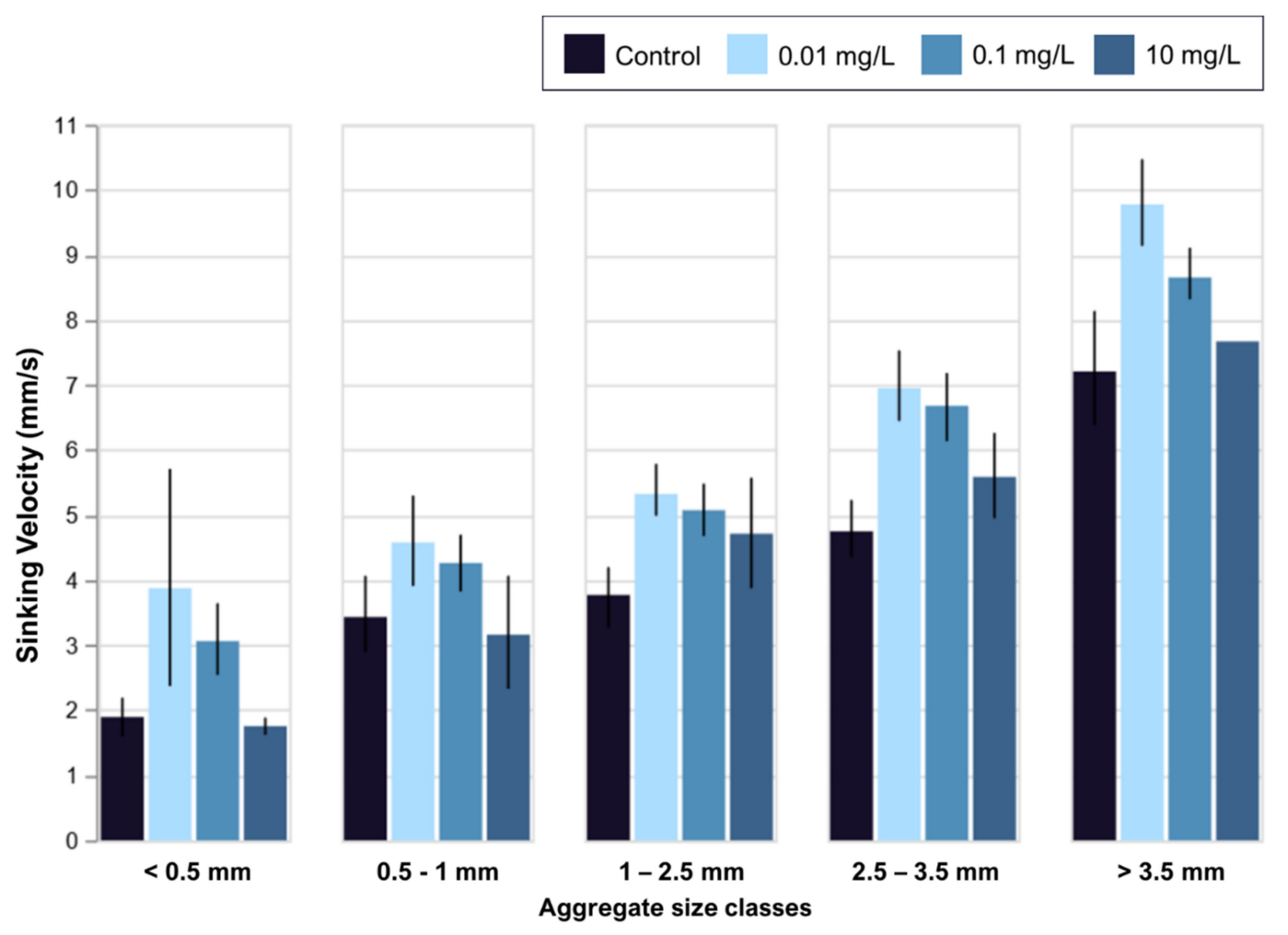

Figure 3. Sinking velocity change with nanoPS exposure. Sinking velocities decrease with aggregate size from more than $7 \mathrm{~mm} / \mathrm{s}(>3.5 \mathrm{~mm})$ to less than $2 \mathrm{~mm} / \mathrm{s}(<0.5 \mathrm{~mm})$. In all class sizes, the control was similar in sinking velocity to the highest nanoPS treatment $(10 \mathrm{mg} / \mathrm{L})$. The low nanoPS treatment $(0.01 \mathrm{mg} / \mathrm{L})$ differed significantly from both controls $\left(t\right.$-test, two-tailed $\left.p=5.56 \times 10^{-4}\right)$ and the highest nanoPS treatment $\left(t\right.$-test, two-tailed $\left.p=9.03 \times 10^{-4}\right)$. This was also true for the intermediate nanoPS treatment (darker blue, $0.1 \mathrm{mg} / \mathrm{L}$ ). Error bars are $95 \%$ confidence intervals. Only one huge aggregate was measured in the highest nanoPS treatment. No differences in sinking velocity were observed in relation to exposure length.

\subsection{NanoPS Effects on Gene Expression}

Analysis of differential gene expression showed that, in Symbiodinium, 14 genes were upregulated after nanoPS 42 exposure, and 34 were downregulated relative to controls (Figure 4a). In Cladocopium, 75 genes were upregulated, and 169 genes were downregulated (Figure 4b). Cladocopium seems more sensitive to nanoPS 42 exposure, as overall more genes responded than in Symbiodinium. Since Pfam analysis had more annotations than BLAST2GO in differentially expressed genes (DEGs) of Cladocopium, we list the major domains encoded by the DEGs of Cladocopium (Tables S3-S6).

The largest group of upregulated genes was a subfamily of dynein-related proteins having an AAA_5 domain (Table 1). Dynein is a microtubule-associated motor protein. Ten genes for dynein-related proteins with AAA and/or DHC (Dynein heavy chain) were upregulated in Cladocopium sp. by nanoPS ${ }_{42}$ (Table 1 and Table S4). It has been shown that microplastic exposure induces production of reactive oxygen species (ROS) in microalgae $[13,33]$ and dynein upregulation. Therefore, it might be needed to balance cytoskeletal dynamics as microtubule polymerization is impaired by oxidative stress [38]. Dynein light chain genes were also shown to be upregulated in gill cells of zebra mussels exposed to polystyrene micro-plastic [39]. 


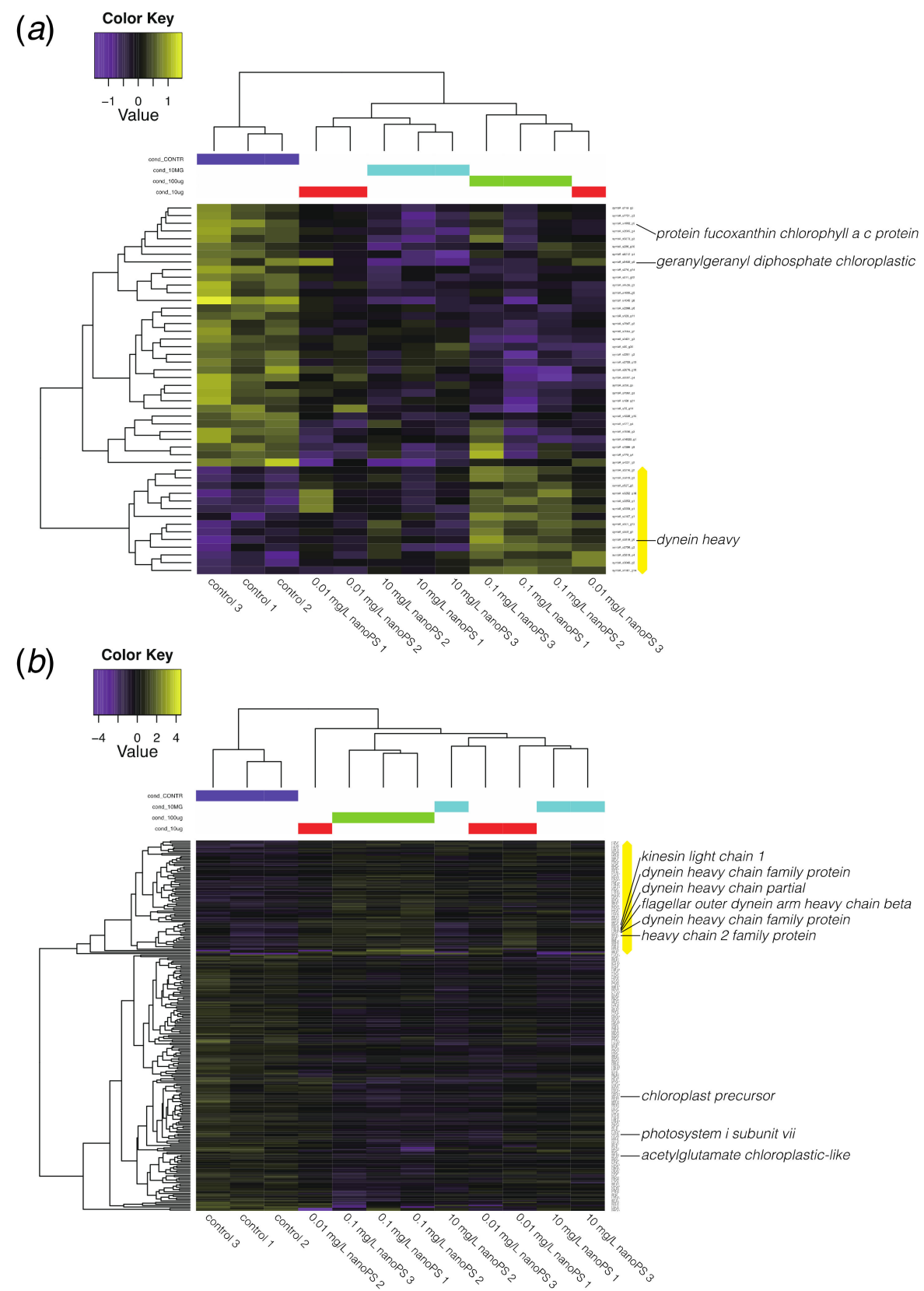

Figure 4. Heatmap and clustering of differentially expressed genes ( 2 -fold changes, $p<0.001$ ) between dinoflagellates exposed to nano-plastics and controls. (a) DEGs in Symbiodinium tridacnidorum. (b) DEGs in Cladocopium sp. Values indicate the relative gene expression level with purple and yellow showing downregulation and upregulation, respectively. The yellow bar shows a cluster of upregulated genes. Annotations by Blast2GO show the presence of microtubule-related or photosynthesis-related genes among DEGs.

Table 1. Domains encoded by more than three up-regulated genes in Cladocopium sp.

\begin{tabular}{llc}
\hline Domain Name & \multicolumn{1}{c}{ Summary from Pfam Database } & Gene Number \\
\hline AAA_5 & AAA domain (dynein-related subfamily) & 6 \\
DHC_N2 & Dynein heavy chain, N-terminal region 2 & 5 \\
AAA & ATPase family associated with various cellular activities & 4 \\
AAA_6 & Hydrolytic ATP binding site of dynein motor region & 4 \\
TIG & IPT/TIG domain & 4 \\
\hline
\end{tabular}


Four upregulated genes in Cladocopium (Table 1) encoded proteins with TIG domains that have an immunoglobulin-like fold and are found in cell surface receptors that control cell dissociation [40,41]. This might contribute to adhesion between neighboring cells and to the extracellular matrix composition and explain some of the changes observed in cell aggregations.

There were more downregulated genes than upregulated genes in both Symbiodinium and Cladocopium (Figure 4). PPR (pentatricopeptide repeat) protein (Table 2) is involved in RNA editing [42] and extensive RNA editing has been reported in organelles of Symbiodiniaceae [43,44]. Five genes for photosynthesis were downregulated (Figure 4). These changes may explain observed reductions in photosystem efficiency in C. goreaui [13].

Table 2. Domains encoded by more than three down-regulated genes in Cladocopium sp.

\begin{tabular}{llc}
\hline \multicolumn{1}{c}{ Domain Name } & \multicolumn{1}{c}{ Summary from Pfam Database } & Gene Number \\
\hline Ank & Ankyrin repeat & 10 \\
Ank_2 & Ankyrin repeats (3 copies) & 10 \\
Ank_3 & Ankyrin repeat & 10 \\
Ank_4 & Ankyrin repeats (many copies) & 10 \\
Ank_5 & Ankyrin repeats (many copies) & 10 \\
PPR_2 & PPR repeat family & 6 \\
RCC1_2 & Regulator of chromosome condensation (RCC1) repeat & 6 \\
ANAPC3 (Apc3) & Anaphase-promoting complex, cyclosome, subunit 3 & 5 \\
Pkinase & Protein kinase domain & 5 \\
PPR & PPR repeat & 5 \\
PPR_3 & Pentatricopeptide repeat domain & 5 \\
Abhydrolase_5 & Alpha/beta hydrolase family & 4 \\
Abhydrolase_6 & Alpha/beta hydrolase family & 4 \\
Lipase_3 & Lipase (class 3) & 4 \\
PPR_1 & PPR repeat & 4 \\
TPR_14 & Tetratricopeptide repeat & 4 \\
YukD & WXG100 protein secretion system (Wss), protein YukD & 4 \\
\hline
\end{tabular}

Other downregulated gene groups were related to intracellular degradation processes, including hydrolase and lipase, and to subunit 3 of the anaphase-promoting complex/cyclosome [45]. The downregulated gene (s3282_g2) with abhydrolase and chlorophyllase domains is likely related to chlorophyll degradation [46]. The gene, s576_g21, for cell division control (CDC) protein 2 is downregulated in Cladocopium. Downregulation of six genes with RCC1 (regulator of chromosome condensation) and three genes with CDC domains suggest some effect on cell division. Thus, several negative consequences of nanoPS 42 exposure are suggested by DEGs (summarized in Figure 5). 


\section{Symbiotic dinoflaggelates cell}

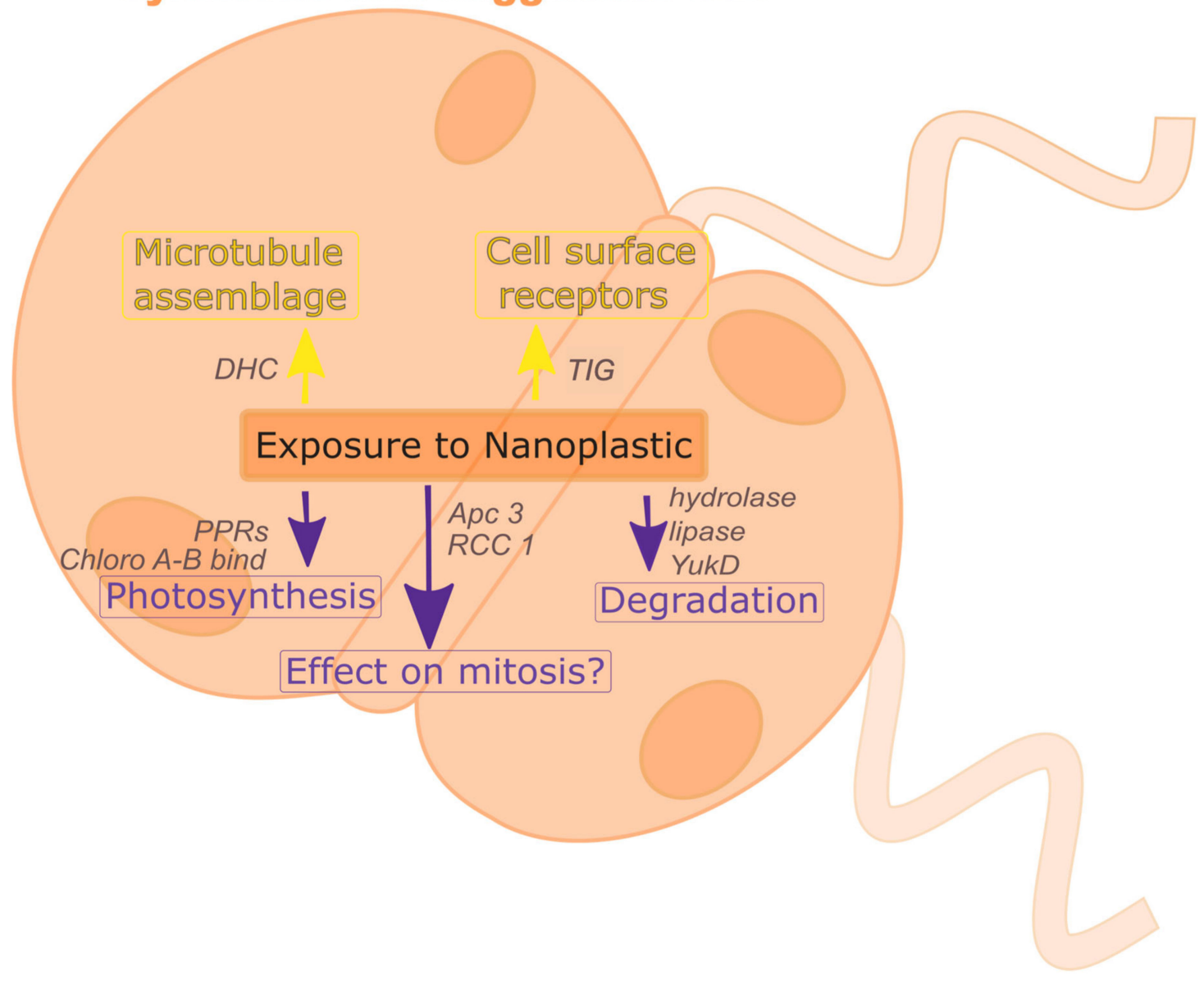

Figure 5. Exposure to nanoPS 42 changes gene expression levels in symbiotic dinoflagellates. Yellow and purple arrows show up-regulation and down-regulation of gene expression, respectively.

\section{Conclusions}

Previous studies have shown that nano-plastics have adverse effects on different algae groups $[32,34,35,47,48]$, and a recent study shows that micro-plastics have similarly negative effects on an endosymbiotic dinoflagellate Cladocopium goreaui [13]. No previous studies have been conducted on nanoPS 42 effects on Symbiodiniaceae. We found significant changes in aggregation, photosystem efficiency, and aggregate sinking velocity of symbiotic dinoflagellates, which is coupled with variations in gene expression patterns after exposure to nanoPS ${ }_{42}$. The reduction in photosystem efficiency and photosystem gene expression patterns could have led to the observed reduced growth rates and are especially problematic given the obligate photosymbiotic nature of the host animals of the dinoflagellates.

Supplementary Materials: The following are available online at http:/www.mdpi.com/2076-2607/8/11/1759/s1. Figure S1: Cell abundance in treatment tanks, control tanks, and outside controls. Figure S2: NanoPS exposure changes aggregation behaviour, reduces cell numbers, and alters size class distributions. Table S1: Relationship between nanoPS ${ }_{42}$ concentration and particles per tank. Table S2: Sampling days of each tank. Table S3: Genes that responded to nano-plastic exposure in Symbiodinium tridacnidorum. Table S4: Genes that responded to nano-plastic exposure in Cladocopium sp. Table S5: Differentially expressed genes with a two-fold difference between the controls and nano-plastic exposure (Symbiodinium tridacnidorum cladeA, TMM FPKM values, $p<0.001$ ). Table S6: Differentially expressed genes with a two-fold difference between the controls and nano-plastic exposure (Cladocopium sp. cladeC, TMM FPKM values, $p<0.001$ ).

Author Contributions: C.R. designed the study and performed the experiment. E.S. carried out RNA analyses. K.K. and C.R. performed RNA-seq mapping and cluster analyses. All authors wrote the manuscript. All authors have read and agreed to the published version of the manuscript. 
Funding: This research received no external funding. This research was funded by Okinawa Institute of Science and Technology Graduate University support for the Light-Matter Interactions for Quantum Technologies (SNC) and the Marine Genomics Unit (NS).

Acknowledgments: We are grateful to the DNA sequencing section of OIST for RNA preparation and sequencing and to the OIST imaging section for 3D image support. We thank members of the MGU, especially Haruhi Narisoko for cell culturing and Kanako Hisata for IT support. We are grateful for the help and support provided by K. Deasy from the Engineering Support Section of Research Support Division at OIST. We gratefully acknowledge Síle Nic Chormaic and Noriyuki Satoh for their continuing personal and material support and kind encouragement throughout the project.

Conflicts of Interest: The authors declare no conflict of interest.

Availability of Data: Data are available in the electronic supplementary material. Raw sequence data are available from PRJNA627564 in NCBI database. Symbiodinium (currently the family Symbiodiniaceae) clade A3 and C genomes: clade A3 (https://marinegenomics.oist.jp/symb/viewer/info?project_id=37) and clade C (https: //marinegenomics.oist.jp/symb/viewer/info?project_id=40). Transcript models of Symbiodinium clades A3 and C: https://marinegenomics.oist.jp/symb/download/syma_transcriptome_37.fasta.gz and https://marinegenomics.oist. jp/symb/download/symC_aug_40.fa.gz.

\section{References}

1. McKinney, M.L. Is Marine Biodiversity at Less Risk? Evidence and Implications. Divers. Distrib. 1998, 4, 3-8.

2. Hughes, T.P.; Anderson, K.D.; Connolly, S.R.; Heron, S.F.; Kerry, J.T.; Lough, J.M.; Baird, A.H.; Baum, J.K.; Berumen, M.L.; Bridge, T.C.; et al. Spatial and temporal patterns of mass bleaching of corals in the Anthropocene. Science 2018, 359, 80-83. [CrossRef] [PubMed]

3. Woodhead, A.J.; Hicks, C.C.; Norström, A.V.; Williams, G.J.; Graham, N.A.J. Coral reef ecosystem services in the Anthropocene. Funct. Ecol. 2019, 1023-1034. [CrossRef]

4. Imhof, H.K.; Sigl, R.; Brauer, E.; Feyl, S.; Giesemann, P.; Klink, S.; Leupolz, K.; Löder, M.G.; Löschel, L.A.; Missun, J.; et al. Spatial and temporal variation of macro-, meso- and microplastic abundance on a remote coral island of the Maldives, Indian Ocean. Mar. Pollut. Bull. 2017, 116, 340-347. [CrossRef] [PubMed]

5. Gillibert, R.; Balakrishnan, G.; Deshoules, Q.; Tardivel, M.; Magazzù, A.; Donato, M.G.; Maragò, O.M.; De La Chapelle, M.L.; Colas, F.J.; Lagarde, F.; et al. Raman Tweezers for Small Microplastics and Nanoplastics Identification in Seawater. Environ. Sci. Technol. 2019, 53, 9003-9013. [CrossRef]

6. Tang, J.; Ni, X.; Zhou, Z.; Wang, L.; Lin, S. Acute microplastic exposure raises stress response and suppresses detoxification and immune capacities in the scleractinian coral Pocillopora damicornis. Environ. Pollut. 2018, 243, 66-74. [CrossRef] [PubMed]

7. Hall, N.M.; Berry, K.L.E.; Rintoul, L.; Hoogenboom, M.O. Microplastic ingestion by scleractinian corals. Mar. Biol. 2015, 162, 725-732. [CrossRef]

8. Connors, E.J. Distribution and biological implications of plastic pollution on the fringing reef of Mo'orea, French Polynesia. PeerJ 2017, 5, e3733. [CrossRef]

9. Axworthy, J.B.; Padilla-Gamiño, J.L. Microplastics ingestion and heterotrophy in thermally stressed corals. Sci. Rep. 2019, 9, 1-8. [CrossRef]

10. Okubo, N.; Takahashi, S.; Nakano, Y. Microplastics disturb the anthozoan-algae symbiotic relationship. Mar. Pollut. Bull. 2018, 135, 83-89. [CrossRef]

11. Hankins, C.; Duffy, A.; Drisco, K. Scleractinian coral microplastic ingestion: Potential calcification effects, size limits, and retention. Mar. Pollut. Bull. 2018, 135, 587-593. [CrossRef]

12. Reichert, J.; Schellenberg, J.; Schubert, P.; Wilke, T. Responses of reef building corals to microplastic exposure. Environ. Pollut. 2018, 237, 955-960. [CrossRef]

13. Su, Y.; Zhang, K.; Zhou, Z.; Wang, J.; Yang, X.; Tang, J.; Li, H.; Lin, S. Microplastic exposure represses the growth of endosymbiotic dinoflagellate Cladocopium goreaui in culture through affecting its apoptosis and metabolism. Chemosphere 2020, 244, 125485. [CrossRef] [PubMed]

14. Ter Halle, A.; Jeanneau, L.; Martignac, M.; Jardé, E.; Pedrono, B.; Brach, L.; Gigault, J. Nanoplastic in the North Atlantic Subtropical Gyre. Environ. Sci. Technol. 2017, 51, 13689-13697. [CrossRef]

15. Nanoplastic should be better understood. Nat. Nanotechnol. 2019, 14, 299. [CrossRef]

16. Gago, J.; Carretero, O.; Filgueiras, A.; Viñas, L. Synthetic microfibers in the marine environment: A review on their occurrence in seawater and sediments. Mar. Pollut. Bull. 2018, 127, 365-376. [CrossRef] 
17. Koelmans, A.A.; Besseling, E.; Foekema, E.; Kooi, M.; Mintenig, S.; Ossendorp, B.C.; Redondo-Hasselerharm, P.E.; Verschoor, A.; Van Wezel, A.P.; Scheffer, M. Risks of Plastic Debris: Unravelling Fact, Opinion, Perception, and Belief. Environ. Sci. Technol. 2017, 51, 11513-11519. [CrossRef]

18. Galloway, T.S.; Cole, M.; Lewis, C. Interactions of microplastic debris throughout the marine ecosystem. Nat. Ecol. Evol. 2017, 1, 116. [CrossRef]

19. Mies, M.; Braga, F.; Scozzafave, M.S.; De Lemos, D.E.L.; Sumida, P.Y.G. Early development, survival and growth rates of the giant clam Tridacna crocea (Bivalvia: Tridacnidae). Braz. J. Oceanogr. 2012, 60, 127-133. [CrossRef]

20. Hirose, M.; Reimer, J.D.; Hidaka, M.; Suda, S. Phylogenetic analyses of potentially free-living Symbiodinium spp. isolated from coral reef sand in Okinawa, Japan. Mar. Biol. 2008, 155, 105-112. [CrossRef]

21. Yamashita, H.; Koike, K. Genetic identity of free-living Symbiodinium obtained over a broad latitudinal range in the Japanese coast: Phylogeny of free-living Symbiodinium. Phycol. Res. 2013, 61, 68-80. [CrossRef]

22. Schoenberg, D.A.; Trench, R.K. Genetic variation in Symbiodinium (=Gymnodinium) microadriaticum Freudenthal, and specificity in its symbiosis with marine invertebrates. I. Isoenzyme and soluble protein patterns of axenic cultures of Symbiodinium microadriaticum. In Proceedings of the Royal Society of London. Series B. Biological Sciences; The Royal Society: London, UK, 1980; 207, pp. 405-427.

23. Long, M.; Moriceau, B.; Gallinari, M.; Lambert, C.; Huvet, A.; Raffray, J.; Soudant, P. Interactions between microplastics and phytoplankton aggregates: Impact on their respective fates. Mar. Chem. 2015, 175, $39-46$. [CrossRef]

24. Shanks, A.L.; Edmondson, E.W. Laboratory-made artificial marine snow: A biological model of the real thing. Mar. Biol. 1989, 101, 463-470. [CrossRef]

25. Shoguchi, E.; Beedessee, G.; Tada, I.; Hisata, K.; Kawashima, T.; Takeuchi, T.; Arakaki, N.; Fujie, M.; Koyanagi, R.; Roy, M.C.; et al. Two divergent Symbiodinium genomes reveal conservation of a gene cluster for sunscreen biosynthesis and recently lost genes. BMC Genom. 2018, 19, 1-11. [CrossRef]

26. Beedessee, G.; Hisata, K.; Roy, M.C.; Van Dolah, F.M.; Satoh, N.; Shoguchi, E. Diversified secondary metabolite biosynthesis gene repertoire revealed in symbiotic dinoflagellates. Sci. Rep. 2019, 9, 1-12. [CrossRef]

27. Arossa, S.; Martin, C.; Rossbach, S.; Duarte, C.M. Microplastic removal by Red Sea giant clam (Tridacna maxima). Environ. Pollut. 2019, 252, 1257-1266. [CrossRef]

28. Cole, M.; Lindeque, P.; Halsband, C.; Galloway, T.S. Microplastics as contaminants in the marine environment: A review. Mar. Pollut. Bull. 2011, 62, 2588-2597. [CrossRef]

29. Passow, U.; Sweet, J.; Francis, S.; Xu, C.; Dissanayake, A.; Lin, Y.; Santschi, P.; Quigg, A. Incorporation of oil into diatom aggregates. Mar. Ecol. Prog. Ser. 2019, 612, 65-86. [CrossRef]

30. Li, B.; Dewey, C.N. RSEM: Accurate transcript quantification from RNA-Seq data with or without a reference genome. BMC Bioinform. 2011, 12, 323. [CrossRef] [PubMed]

31. Robinson, M.D.; Oshlack, A. A scaling normalization method for differential expression analysis of RNA-seq data. Genome Biol. 2010, 11, R25. [CrossRef]

32. Prata, J.C.; Lavorante, B.R.; Montenegro, M.D.C.B.; Guilhermino, L. Influence of microplastics on the toxicity of the pharmaceuticals procainamide and doxycycline on the marine microalgae Tetraselmis chuii. Aquat. Toxicol. 2018, 197, 143-152. [CrossRef] [PubMed]

33. Lagarde, F.; Olivier, O.; Zanella, M.; Daniel, P.; Hiard, S.; Caruso, A. Microplastic interactions with freshwater microalgae: Hetero-aggregation and changes in plastic density appear strongly dependent on polymer type. Environ. Pollut. 2016, 215, 331-339. [CrossRef]

34. Zhang, C.; Chen, X.; Wang, J.; Tan, L. Toxic effects of microplastic on marine microalgae Skeletonema costatum: Interactions between microplastic and algae. Environ. Pollut. 2017, 220, 1282-1288. [CrossRef]

35. Nolte, T.M.; Hartmann, N.B.; Kleijn, J.M.; Garnæs, J.; Van De Meent, D.; Hendriks, A.J.; Baun, A. The toxicity of plastic nanoparticles to green algae as influenced by surface modification, medium hardness and cellular adsorption. Aquat. Toxicol. 2017, 183, 11-20. [CrossRef]

36. Logan, B.E.; Alldredge, A.L. Potential for increased nutrient uptake by flocculating diatoms. Mar. Biol. 1989, 101, 443-450. [CrossRef]

37. Andersen, K.P.; Dam, H.G. Coagulation efficiency and aggregate formation in marine phytoplankton. Mar. Biol. 1990, 107, 235-245. [CrossRef]

38. Ewilson, C.; González-Billault, C. Regulation of cytoskeletal dynamics by redox signaling and oxidative stress: Implications for neuronal development and trafficking. Front. Cell. Neurosci. 2015, 9, 381. [CrossRef] 
39. Magni, S.; Della Torre, C.; Garrone, G.; D'Amato, A.; Parenti, C.; Binelli, A. First evidence of protein modulation by polystyrene microplastics in a freshwater biological model. Environ. Pollut. 2019, 250, 407-415. [CrossRef] [PubMed]

40. Collesi, C.; Santoro, M.M.; Gaudino, G.; Comoglio, P.M. A splicing variant of the RON transcript induces constitutive tyrosine kinase activity and an invasive phenotype. Mol. Cell. Biol. 1996, 16, 5518-5526. [CrossRef]

41. Bork, P.; Doerks, T.; Springer, T.A.; Snel, B. Domains in plexins: Links to integrins and transcription factors. Trends Biochem. Sci. 1999, 24, 261-263. [CrossRef]

42. Barkan, A.; Walker, M.; Nolasco, M.; Johnson, D. A nuclear mutation in maize blocks the processing and translation of several chloroplast mRNAs and provides evidence for the differential translation of alternative mRNA forms. EMBO J. 1994, 13, 3170-3181. [CrossRef]

43. Mungpakdee, S.; Shinzato, C.; Takeuchi, T.; Kawashima, T.; Koyanagi, R.; Hisata, K.; Tanaka, M.; Goto, H.; Fujie, M.; Lin, S.; et al. Massive Gene Transfer and Extensive RNA Editing of a Symbiotic Dinoflagellate Plastid Genome. Genome Biol. Evol. 2014, 6, 1408-1422. [CrossRef]

44. Shoguchi, E.; Shinzato, C.; Hisata, K.; Satoh, N.; Mungpakdee, S. The Large Mitochondrial Genome of Symbiodinium minutumReveals Conserved Noncoding Sequences between Dinoflagellates and Apicomplexans. Genome Biol. Evol. 2015, 7, 2237-2244. [CrossRef] [PubMed]

45. Peters, J.-M. The anaphase promoting complex/cyclosome: A machine designed to destroy. Nat. Rev. Mol. Cell Biol. 2006, 7, 644-656. [CrossRef]

46. Tsuchiya, T.; Ohta, H.; Okawa, K.; Iwamatsu, A.; Shimada, H.; Masuda, T.; Takamiya, K.-I. Cloning of chlorophyllase, the key enzyme in chlorophyll degradation: Finding of a lipase motif and the induction by methyl jasmonate. Proc. Natl. Acad. Sci. USA 1999, 96, 15362-15367. [CrossRef]

47. Besseling, E.; Wang, B.; Lürling, M.; Koelmans, A.A. Nanoplastic Affects Growth of S. obliquus and Reproduction of D. magna. Environ. Sci. Technol. 2014, 48, 12336-12343. [CrossRef]

48. Bellingeri, A.; Casabianca, S.; Capellacci, S.; Faleri, C.; Paccagnini, E.; Lupetti, P.; Koelmans, A.A.; Penna, A.; Corsi, I. Impact of polystyrene nanoparticles on marine diatom Skeletonema marinoi chain assemblages and consequences on their ecological role in marine ecosystems. Environ. Pollut. 2020, 262, 114268. [CrossRef]

Publisher's Note: MDPI stays neutral with regard to jurisdictional claims in published maps and institutional affiliations.

(C) 2020 by the authors. Licensee MDPI, Basel, Switzerland. This article is an open access article distributed under the terms and conditions of the Creative Commons Attribution (CC BY) license (http://creativecommons.org/licenses/by/4.0/). 